\section{ambient \\ SCIENCE \\ Vol. 05(Sp2):08-11 \\ Year 2018}

\title{
Stabilization of Soil under Foundation and Pavements Using Fly Ash
}

\section{Aditya Pandey, Divyanshu Tiwari, Durgesh Kumar Yadav, Ram Krishna Mishra*, Vaibhav P. Deshpande, Ankit Shinde}

Department of Civil Engineering, Bhilai Institute of Technology, Raipur, Chhattisgarh, India

\section{Study Area: RaipurChhattisgarh, India Coordinates: $21.25^{\circ} \mathrm{N} ; 81.63^{\circ} \mathrm{E}$}

Key words: Black cotton soil, Modified Proctor Test, Plasticity and liquid limit.

\section{Introduction:}

The soil stabilization is the process of improving theengineering property of the soil by either mechanical or by chemical method. The mechanical method of soil stabilization can be achieved by altering the basic nature of virgin soil by either induced vibration or by compaction. The chemical method of soil stabilization depends on the chemical reactions between stabilizer and soil minerals. This particular method was adopted in our study i.e., the soil stabilization by the process of chemical stabilization.

Black cotton soil (Loose Soil) has a clay content namely known as Montmorillonite. Black cotton soil when gets wet, it swells and when dried it gets shrink. Thus such clays are unf it for construction purposes (Arora \& Aydilek, 2005).

Fly-ash is a by-product of the burning of coal. It is abundant in nature and is always treated as the waste material produced by thermal power plants all over India. The effective fly-ash content which improves the engineering properties of soil ranges between $15-20 \%$ (Pandian et al., 2002). It has been proposed that fly-ash can be used in embankments and fills. In this piece of work, the effect of different percentages of fly-ash in addition to black cotton soil on California Bearing Ratio (CBR) values was tested (Pandian et al., 2001). Black cotton (BC) soil is expansive in nature due to its combination of clay with an expanding lattice structure (Murthy et al., 200o; Sridharan et al., 1998). Lime and fly-ash change the soil property by a

\section{$\underline{\text { Abstract }}$}

State Chhattisgarh of India is having a vast area covered under forest and agricultural land. The black cotton soil is available in the vicinity of water bodies like ponds, regular/monsoon nallahs etc. Infrastructure projects like the houses in the villages and for the low-income grade communities, widening of national highways and new highways etc. requires a huge amount of soil (mud) for filling of sub-base preparation. Since black cotton soil shows properties like swelling and shrinkage with an effect of moisture, it needs stabilization other commercial uses. This work consists of an evaluation of soil properties on the addition of locally available industrial by-product which must be under budget. The present piece of work is an attempt to see the effect of fly-ash (industrial by-product) on stabilization of soil lies under such foundation and Pavements.

chemical reaction where as other admixtures changes mechanical soil nature. Till date, few attempts have been carried out for improving engineering properties of poor soils using different additives (Nagraj et al.,1994; Edil et al., 2006; Muley et al., 2010). Indeed most of the attempts had made to correlate California Bearing Ratio with basic soil properties. But, we have used fly-ash, a waste material to enhance the soil properties by (Fig.-1).

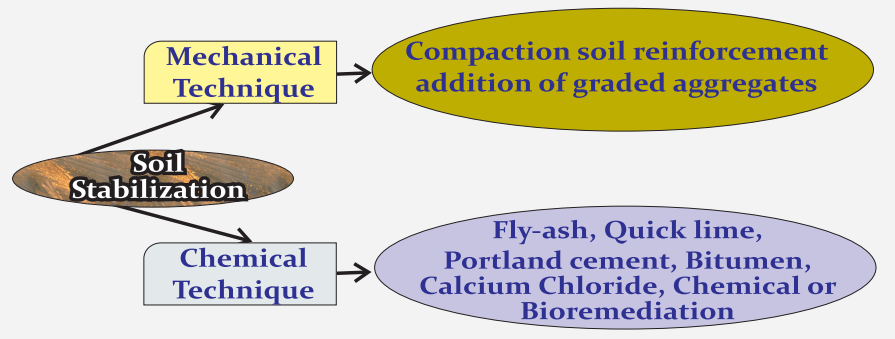

Figure-1: The methodology adopted by us in our study

\section{Methodology:}

Fly-ash and bottom ash were collected from NTPC-SAIL Power Corporation Limited (NSPCL) Bhilai and Dr. Shyama Prasad Mukherjee (DSPM)Thermal Power Station (TPS) Korba thermal power plants. Fly-ash was collected from the silos exist in those thermal power plants. As per the report of the power plants by Government of India in 20173500 metric tonnes of fly-ash have been produced regularly from the DSPM TPS Korba power plant and 15000 metric tonnes 
from NSPCLBhilai. But the utilization is around 33\% of the total generated fly-ash. The total of $5 \mathrm{o} \mathrm{kg}$ of both fly-ash and bottom ash were collected from the thermal power stations. Both were dried in an oven before use.

Table-1: Constituents of Fly-ash collected from both the power plants

\begin{tabular}{lll}
\hline Compound & Plant-1(NTPC-SAIL) & Plant-2 (DSPM) \\
\hline $\mathrm{SiO}_{2}$ & $62.32 \%$ & $56.85 \%$ \\
$\mathrm{Al}_{2} \mathrm{O}_{3}$ & $26.72 \%$ & $21.40 \%$ \\
$\mathrm{Fe}_{2} \mathrm{O}_{3}$ & $08.00 \%$ & $13.82 \%$ \\
$\mathrm{CaO}$ & $00.50 \%$ & $03.29 \%$ \\
$\mathrm{MgO}$ & $00.57 \%$ & $00.74 \%$ \\
$\mathrm{So}_{3}$ & $00.18 \%$ & $00.00 \%$ \\
$\mathrm{Na}_{2} \mathrm{O}$ & $00.10 \%$ & $00.00 \%$ \\
$\mathrm{~K}_{2} \mathrm{O}$ & $00.52 \%$ & $01.85 \%$ \\
$\mathrm{Ti}_{2} \mathrm{O}_{3}$ & $00.04 \%$ & $00.00 \%$ \\
$\mathrm{P}_{2} \mathrm{O}_{5}$ & $1.05 \%$ & $00.00 \%$ \\
\hline
\end{tabular}

Soil was collected from the outskirt of Raipur city of Chhattisgarh.These samples have been identified for their swell potential and have been broadly grouped into three categories based on their degree of expansiveness and problematic nature as (i) Highlyexpansive and problematic group, (ii) Moderatelyexpansive and problematic group and (iii) Leastexpansive and problematic group (Hakari \& Puranik, 2010)

Engineering properties of soil which have been considered in this work were: Liquid Limit, Plastic Limit, Plasticity Index, Specific Gravity, Classification Group, Differential Free, Swell Index, Optimum Water Content, Maximum Dry Density

\section{Results and Discussion:}

Variation of liquid and plastic limits on replacement of soil have been shown in Fig.- 2.

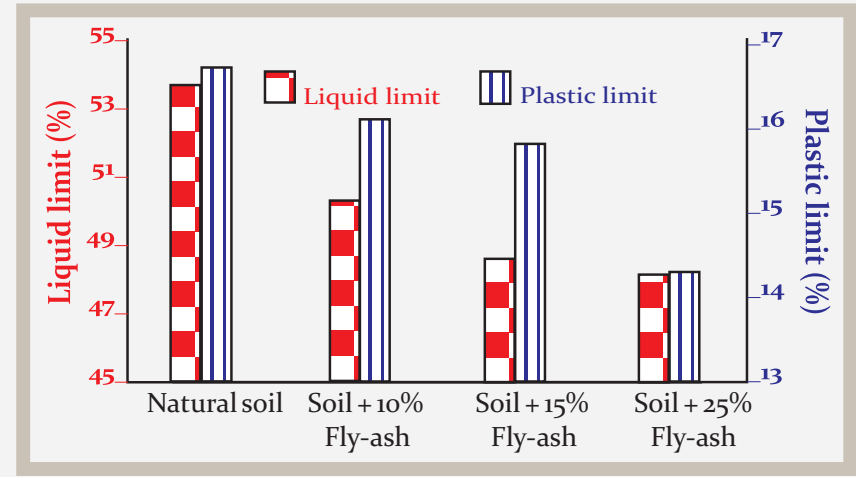

Figure-2: Liquid limitversus plastic limit on soil remold

fly-ash has more liquidity than that of natural soil which had plastic behavior. The liquid limit decreases with increase in fly-ash content from $0 \%$ to $25 \%$. The reduction in the liquid limit was found out to be $5.55 \%$. On the other hand, the plastic limit of the soil decreases with increase in the percentage of fly-ash from $0 \%$ to $25 \%$ which indicates that on an addition of fly-ash the soil loses its plastic state. It means that the soil started to act like sand. As on addition of
Fly-ash to the soil, the soil started losing its cohesive nature and thus it was observed that soil changed into the cohesionless soil which resembles sand. This indicates a good sign for the tackling of the unequal settlement of the soil during the construction process.

Free swell index(F.S.I.): the free swell index was performed in a $100 \mathrm{ml}$ cylinder jar with $10 \mathrm{~g}$ soil sample (IS: 2720 (Part 40) - 1985, Determination of Free Swell Index). The results are shown in Table-3. The relations between swelling behavior and mixture prepared have been shown in Fig.- 4 \& Fig.- 5. After conducting the free swell index it was observed that as the water content increased the soil swell or concomitantly the plasticity also increased with an increase in the Liquid limit. Therefore F.S.I. also increased with increases in the plasticity index, which in turn revealed swelling and shrinkage properties in the soil.

Table 3 Free Swell Index with various solvents

\begin{tabular}{lccc}
\hline Soil Type & Kerosene & Water & FSI \\
\hline Natural Soil & $11 \mathrm{ml}$ & $18.5 \mathrm{ml}$ & $68.18 \%$ \\
fly-ash & $10 \mathrm{ml}$ & $11 \mathrm{ml}$ & $10 \%$ \\
Soil + 10\% fly-ash & $10.5 \mathrm{ml}$ & $14.5 \mathrm{ml}$ & $41.06 \%$ \\
Soil + 15\% fly-ash & $10 \mathrm{ml}$ & $12.75 \mathrm{ml}$ & $27.5 \%$ \\
Soil + 25\% fly-ash & $9 \mathrm{ml}$ & $11 \mathrm{ml}$ & $\mathbf{2 2 . 2 2} \%$ \\
\hline
\end{tabular}

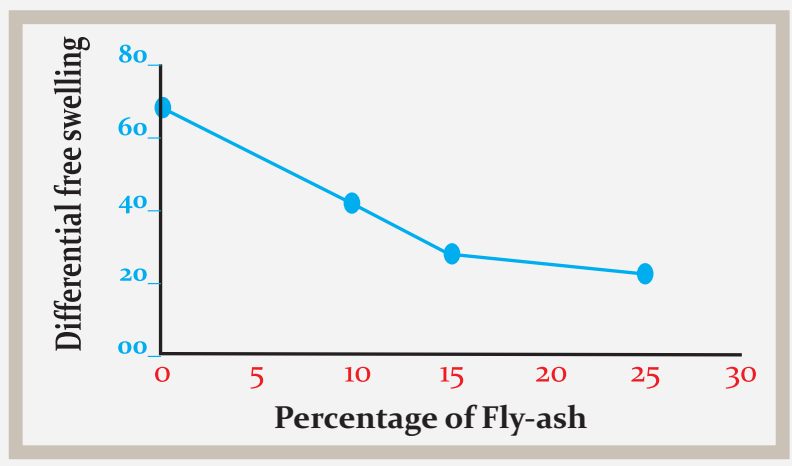

Figure-3: Variation in Swell Property with respect to Fly-ash

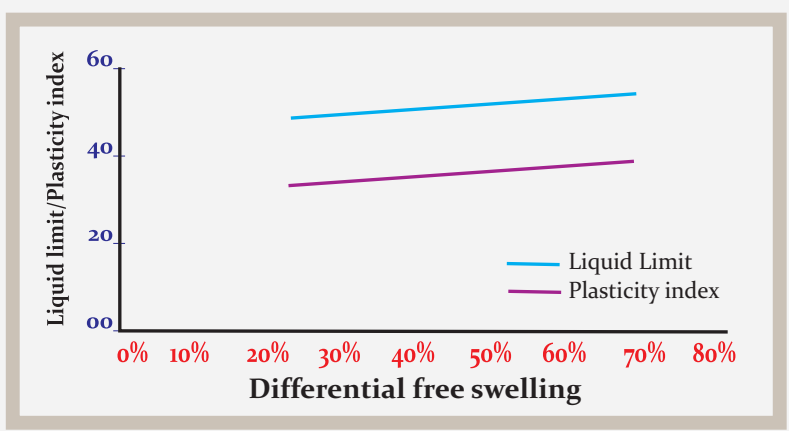

Figure-4: Variation of Atterberg's Limits with respect to Swelling

Modified Proctor Test: since the degree of compaction of soil is measured as the dry density of soil, the degree of compaction is dependent on compaction energy, type of soil and moisture content. The soil attains a maximum dry density at a particular water content which is termed as 
optimum water content (IS: 2720 (Part 7)-1985, Modified Proctor Test). Compaction in the form of increased in dry density is presented in Table-3; plotted in Fig.-5 and Fig.-6.

Table 4 Modified Proctor Test

\begin{tabular}{ccc}
\hline Soil + fly-ash & Optimum Water Content & Dry Density \\
\hline $0 \%$ & $12.5 \%$ & $1.862 \mathrm{gm} / \mathrm{cc}$ \\
$10 \%$ & $14.8 \%$ & $2.38 \mathrm{gm} / \mathrm{cc}$ \\
$15 \%$ & $19.05 \%$ & $3.84 \mathrm{gm} / \mathrm{cc}$ \\
$25 \%$ & $18.14 \%$ & $3.78 \mathrm{gm} / \mathrm{cc}$ \\
\hline
\end{tabular}

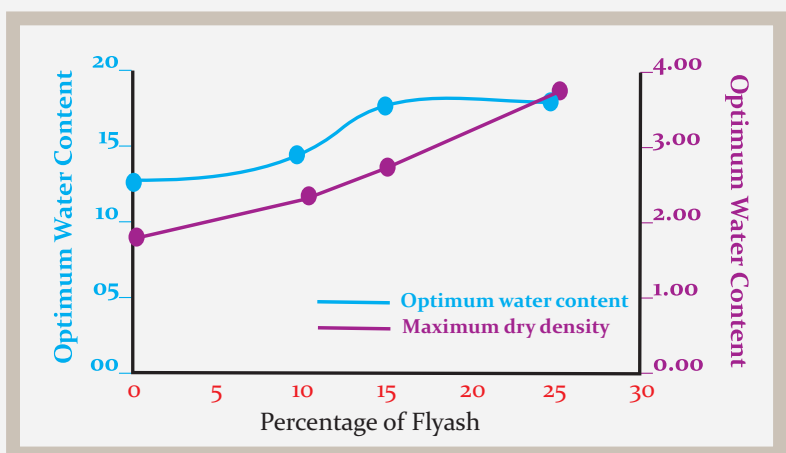

Figure-5: Variation in optimal water content and maximum dry density with respect to Fly-ash

The optimum water content of the soil when mixed with varying percentages of fly-ash increased upto $15 \%$ and then decreased to $25 \%$, thus increasing the maximum dry density from $1.862 \mathrm{gm} / \mathrm{cc}$ to $3.84 \mathrm{gm} / \mathrm{cc}$ at varying percentages from o $\%$ to $15 \%$ and there on decreameant to $3.78 \mathrm{gm} / \mathrm{cc}$ at $25 \%$. This indicates that the soil when mixed with fly-ash gives optimum results at an around $15 \%$.

Specific Gravity : the specif ic gravity of the samples such as fly-ash and soil was determined as per IS 2720 (Part-III; IS: 2720 (Part III) - 1985, Determination of Specif ic gravity of soil). On determination through IS 2720 (Part-III) specif ic gravity of fly-ash was found out to be 2.16 and that of soil was 2.63.

Soil Classification: on conducting sieve analysis of the soil by passing through $4.75 \mathrm{~mm}$ gauge was $100 \%$ and thus it was considered as Sand (S). Since on sieving the soil while passing percentage through $75 \mu$ was $18 \%$ i.e. less than $50 \%$. Thus the soil could be classified as coarse-grained soil. Since fineness is greater than $12 \%$ it could be either termed as Silt (M) or Clay (C).

$\begin{array}{ll}\text { Since, } & \text { IP }=37 \% \\ \text { As per IS 1498-1970, } & \text { if IP }>7, \\ & \mathrm{C}>\mathrm{M} \\ \text { As per A - } & \text { Line Equation }=\left(\text { IS } 1498-1970^{*},\right. \\ & \mathrm{IP}=24.57 \% \\ \text { As per U - } & \text { Line Equation }=\left(\mathrm{IS}_{1498-1970}\right)^{*} \\ & \text { IP }=41.103 \% \\ & \text { *Classification and Identification of } \\ & \text { Soils for GeneralEngineering Purposes. }\end{array}$

The plasticity chart soil is classif ied in SC (IS 1498-1970,
Classification and Identification of Soils for General Engineering Purposes). Since the IP of the soil found was above A - line (24.51\%) and below U - line (41.10\%) and the liquid limit was greater than $50 \%$ and as per IS $1498-1970$ it could be referred as highly compressible soil. These properties of soil match with Black cotton soil (Loose Soil). $\mathrm{pH}-$ Fly-ash is found to be acidic in nature but on addition of fly-ash to the soil, no variation has been found and thus the soil as a whole was observed as neutral i.e. it lies within 6.5-8.5.

Cost analysis :when we use moorum (red laterite soil), the cost of stabilization increases upto 6 times and also disturb the natural resources, whereas when using Soil+15\% Fly-ash it could be economical i.e. upto $35 \%$ reduction in cost, as the fly-ash has to be provided free of cost in vicinity of thermal power plants i.e., within $150 \mathrm{~km}$. This makes the stabilization quite economical and thus reducing the harm to mother earth by utilization of the fly-ash instead of disposing it in nature. It is to be noted that fly-ash not only pollutes the environment but also is a hazard to human being.

Pandian et.al.(2002) reported the benef icial aspects of the fly-ash soil mixes in road construction from Raichur and Neyveli fly-ash on the CBR characteristics of black cotton soils from Karnataka, India. Çokça (2001) studied the effect of fly-ash on expansive soils and he concluded that fly-ash can be recommended as an effective stabilizing agent for the improvement of expansive soils. Phanikumar \& Sharma (2004) presented the effect of fly-ash on free swell index, swell potential, plasticity, compaction, strength characteristics of expansive soils and concluded that the fly-ash improves the plasticity, compaction and strength characteristics of black cotton soils obtained from Andhra Pradesh, India. Report of Sivapullaiah et.al.(1996) suggested that the addition of fly-ash decreased the liquid limit of black cotton soils, they also reported the effect of fly-ash on the index properties of these soils from Karnataka, India.

\section{Conclusions:}

Soil properties improve on an addition of fly-ash upto $25 \%$, which may be due to the filling up of fly-ash in the airvoids of soil. Thus enhancing the rigidity of the soil.

A liquid limit decreased with an increase in the percentage of fly-ash upto $25 \%$ in the natural soil thus it could be concluded that the mixing fly-ash in specific proportion with the soil is an effective way to tackle the problem of shrinkage, swelling and unequal settlement.

The liquid limit of fly-ash didn't show any change in its property due to the absence of cohesive nature of flyash.

Approximately $25-35 \%$ cost may be reduced on use of fly-ash as a replacement and preservation of mother 
earth may be observed.

The plasticity index of the remolded soil is indicative of the plastic capacity of the soil which was observed as a decreasing value as the proportions of fly-ash was increased. The plasticity index showed a decreasing trend as the plastic and liquid limit both were decreasing on regular basis (Arora, 2009)

The optimum water content was found to increase with the addition of fly-ash in different proportions as the water required by the fly-ash present in the soil is very fine and therefore water content needed to be increased (IS: 2720 (Part 40) - 1985, Determination of FreeSwell Index).

The maximum dry density was found to increase due to the increase in optimum water content of the flocculated soil.

Acknowledgment:

We are thankful to Principal Dr.Piyush Kant Pandey of BIT Raipur for providing us facilities to undergo our work on stabilization of soil under pavements and foundation using fly-ash. The support of CSPGCL and NSPCL officials for providing fly-ash and in organizing and executing the field tests is also acknowledged. We also acknowledge the encouragement and advice from Dr. L K Yadu, NIT Raipur..

\section{References:}

Arora, K.R. (2009): Soils Mechanics and Foundation Engineering (Geotechnical engineering) 7th Edition. Pub. by: Standard Publishers, Distributors, Delhi. 953p.

Arora, S. \& Aydilek, A.H. (2005): Class F Fly-Ash-Amended Soils as Highway Base Materials. L. Mater. Civil Eng., 17 (6):640-649.

Çokça,E.,20o1, Use of Class C Fly Ashes for the Stabilizationof an Expansive Soil. L.Mater. Civil Eng.,127(7):568-573.

Edil, T.B., Acosta, H.A. \& Benson, C.H. (2006): Stabilizing Soft Fine-Grained Soils with Fly Ash J. Mater. Civil Eng.,18(2): 283-294.
Hakari, U.D. \& Puranik, S.C. (2010): Evaluation of swell potential and identif ication of expansive and problematic soils in civil engineering works by newly developed matrices based on index and grain size properties. Electron. J. Geotech. Eng., 15(2010):1712-1721.

Madurwari, K.V., Dahale, P.P. \& Burile, A.N. (2013): Comparative study of black cotton soil stabilization with RBI Grade 81 and sodium silicate. Int. J.Innov. Res. Sci. Eng. Technol., 2(2):493499.

Muley, P., Jain, P.K. \& Jain, R. (2010): Experimental Studies on Utilization of Murrum as Hard Shoulder Material. Int. J. Eng. Sci. Technol., 2(9):4896-4901.

Murthy, A.V.S.R., Guru, U.K. \& Havanagi, V.G. (2000): Construction of road embankments using fly ash, fly ash disposal and deposition: beyond $2000 \mathrm{AD}$. Pub. by: Narosa Publishing House, New Delhi, pp. 198-203.

Nagraj, T.S. \& Srinivasa, B.R.(1994): Analysis and Prediction of Soil Behaviour. Pub. by: Taylor \& Francis. 308 p.

Pandian, N.S., Krishna, K.C. \& Leelavathamma, B., (2002): Effect of fly ash on the CBR behaviour of soils. Proceedings of Indian Geotechnical Conference, Allahabad, India vol.1,pp.183-186.

Pandian, N.S. , Krishna, 1 K. C. \& Sridharan, A. (2001): California Bearing Ratio Behavior of Soil/Fly Ash Mixtures. J. Test. Eval., 29(2):220-226.

Phanikumar, B.R. \& Sharma, R. S. (2004): Effect of fly ash on engineering properties of expansive Soil. J. Geotech. Geoenviron. Eng., 130(7):764-767.

Shivapullaiah, P.V., Prashanth,J.P. \& Sridharan, A. (1996): Effect of fly ash on the index properties of black cotton soil. Soils Found., 36(1):97-104.

Sridharan, A., Pandian, N.S., \& Srinivasa Rao, P. (1998): Flyash as a Construction Material in Embankments. 4th International Symposium on Environmental Geotechnology and Global Sustainable Development, Boston (Danvers), Massachusetts, USA 